\title{
Encountering Muslim 'Others': Indonesians in the Muslim Diaspora of London
}

\author{
Amika Wardana ${ }^{1 凶}$ \\ ${ }^{1}$ Sociology Education Programme, Universitas Negeri Yogyakarta, Indonesia
}

Permalink/DOI: http://dx.doi.org/10.15294/komunitas.v6i2.3078

Received : July 2014; Accepted: August 2014; Published: September 2014

\begin{abstract}
The article investigates the social relations between Indonesian immigrants and the multicultural Muslim community in London by examining the applicability of the Ummah concept, in the context of the diaspora. The Muslim diaspora, though their similarity of faith, has always contained internal diversity and fragmentation. Likewise, different religious trajectories of Muslim immigrants as illustrated by Indonesians in London have been identified to shape different understandings of unity and diversity of Muslims, which forge different forms of social relation with fellow Muslim immigrants in the city. The traditionalist London Indonesians have trivialized the unity of Muslim in diaspora through daily encounters yet maintained inevitable different ethnic affinities and religious-sectarian affiliations as a wall dividing them altogether. The revivalist Indonesians have construed the diasporic unity of Muslims as an idealized-normative concept that should be realized socially, culturally and politically by suppressing internal ethnic, national and religious-sectarian fragmentations. While the secularist Indonesians have shown an apathetic position to the implausibility of the diasporic unity of Muslims due to its irreconcilable perceived internal diversities and divisions.
\end{abstract}

\begin{abstract}
Abstrak
Artikel ini menelaah pola relasi sosial antara imigran Indonesia dengan masyarakat Muslim multikultural di London dengan menguji kesesuaian konsep kesatuan Ummat Islam dalam konteks diaspora. Meskipun memiliki persamaan iman, diaspora Muslim selalu terbangun dalam perbedaan internal dan perpecahan. Demikian pula dengan arah perkembangan religiusitas imigran Muslim yang beraneka-ragam termasuk yang berasal dari Indonesia yang pada akhirnya membentuk beberapa pola relasi sosial dengan komunitas Muslim lainnya di kota ini. Kelompok Muslim Indonesia tradisional menganggap biasa konsep kesatuan Ummat Islam dalam perjumpaan sehari-hari dengan komunitas Muslim lainnya sehingga tetap menjaga jarak berdasarkan perbedaan etnis dan afiliasi tradisi keagamaannya. Kelompok Muslim Indonesia revivalist memahami kesatuan Ummat sebagai konsep ideal yang perlu direalisasikan dalam kehidupan sosial, budaya dan politik sekaligus mengubur potensi perpecahan karena perbedaan etnis dan tradisi keagamaan. Sebaliknya, kelompok imigran Indonesia sekuler menunjukkan sikap apatis terhadap kesatuan Ummat karena adanya perbedaan dan perpecahan internal Ummat Islam yang tidak mungkin didamaikan.
\end{abstract}

Keywords: muslim diaspora; muslim unity; Indonesian diaspora

How to Cite: Wardana, A. 2015. Encountering Muslim 'Others': Indonesians in the Muslim Diaspora of London. Jurnal Komunitas, 6(2):197-211. doi:http://dx.doi.org/10.15294/komunitas.v6i2.3078

(C) 2014 Semarang State University. All rights reserved 


\section{INTRODUCTION}

This article elaborates on the patterns of social interaction built up by Indonesian Muslim immigrants in London with fellow immigrant co-religionists including IndoPakistanis, Bangladeshis, Arabs, Somalis and other ethnic and national groups. I argue that Indonesian and Muslim immigrants generally, regardless of their ethnic, racial, national, religious or sectarian differences have tended to coalesce due to sharing Islamic faith and hence the fate of being marginalized and negatively stigmatized as a (security) threat by the receiving society in the West. Importantly, the coalescence has been inspired by invocation of the theological and normative idea of unity within the Muslim community, the Ummah, in the context of the diaspora. Yet the Ummah itself has inherited a certain paradox in that it entails a dual conceptual and historical connotation, those being unity and diversity within the Muslim community. Suffice to say, the coalescence of Muslim immigrants in the diaspora is limited since their dual sense of unity and diversity has been interchangeably reconstituted, experienced and articulated. Focusing on the experience of Indonesian immigrants in London, the chapter examines the applicability of the paradoxical concept of unity and diversity within the Ummah in shaping their social interaction and coalescence with fellow immigrant co-religionists in the city.

Primarily, the article explores the conceptual paradox of unity and diversity within the Muslim community in order to provide a background to the discussion of the coalescence of Indonesians with fellow Muslim immigrants in London. As a religious community defined by a unified religious faith, the idea of Muslim unity is grounded in Islamic theological roots, the Ummah, and endorsed by contingent historical narratives since the early development of the Muslim community. However, other sources from both Islamic texts and historical records delineate the persistence of internal differences and fragmentation within the Muslim community as well. Both unity and diversity are considered to be packaged together as a theological and historical paradox of the Muslim community. Alternatively, as the article argues, it makes sense to explore the way Muslims grasp the sociological meanings of unity and diversity within their own religious community. Muslims might unite and/or divide in certain ways and for different purposes and situations.

The following section of the article explores the ways Indonesian immigrants in London construe and experience unity and diversity within the Muslim diaspora and how the idealized concept of the Ummah inspires their patterns of social interaction with fellow Muslim immigrants. The exploration is primarily based on the polarized ethno-religious and secularized trajectories of Indonesian immigrants in London, (i) the traditionalists; (ii) the revivalists; and (iii) the secularists. I argue that those different ethno-religious and secularized trajectories have a tremendous influence on their different socio-religious orientations, to either remain around their own ethnic group, to coalesce with fellow Indo-Pakistani or Arab co-religionists or to detach from both groups altogether. Additionally, the section focuses on how the persistence of ethnic and national boundaries between them and fellow immigrant co-religionists shapes understandings of unity and diversity within the Muslim diaspora.

\section{METHODS}

This is an ethnographic research study whose main purpose was to gain in-depth understanding and qualitative accounts of the complex relationship built up by Indonesians and fellow Muslim immigrants in London. I concur with Theodoros Iosifides (2011) that the complexity of the issue of immigration, especially Indonesian immigration, conceived of as evolving through the interplay between immigrant actors and the multi-layered societal structures they act in, can be better explained by qualitative ethnographic work than by quantitative survey methodologies.

However, due to Indonesian immigrants live scattered across boroughs of London from North to South and East to West, 
to carry out single-site ethnographic fieldwork was not possible. I adopted, instead, the strategy of 'follow the people' taken from Marcus' (1995) original multi-site ethnography (see also Nadai \& Maeder, 2005 on multi-site ethnography in sociological research). In other words, instead of focusing on a single site such as a neighborhood or borough, the boundaries of the research field were not clearly defined and deferred to the various locations where the informants lived. The multi-site ethnographic fieldwork was conducted over six months from January to June 2010 across the Greater London area. Preliminary visits to the field were made in October and November 2009 and several post-fieldwork visits were made in the period between March and June 2011. The method of gathering data was participant observation combined with life-history interviews focusing on the socio-religious life of Indonesian immigrants and their socio-religious associations and activities as part of their patterns of social relationship with fellow Muslim immigrants.

For the purposes of the study, I conducted life-history interviews involving forty-eight Indonesian Muslim immigrants (twenty females and eighteen males across different socio-economic and educational backgrounds, religious and secularized trajectories) for about one to two hours each. I visited twenty-eight of them in their home for the interview and stayed one or two nights with five families. For the rest of the informants, I interviewed them in coffee shops, office receptions and other places such as the Indonesian Embassy in London and the house of the Indonesian Islamic Centre where we met after the pengajian. In order to follow the confidentiality principle, all names used in the article are pseudonyms.

\section{RESULTS AND DISCUSSION}

The term 'Muslim community' had until recently always denoted the religious connection of people on the basis of their shared Islamic faith. Recently, the term has found new currency in (i) the context of the internationalization of Muslim affairs; (ii) the advent of media and information technologies linking Muslims across the world virtually; and (iii) the formation of minority ethno-religious Muslim immigrant communities in the West. The use of the term 'Muslim community' or the Ummah, in singular form, has thus been exerted either to group (immigrant) Muslims as if a homogenous religious community or to mobilize a sense of unity, collectiveness and solidarity either for religious, cultural or political purposes requiring articulation (Mandaville, 20o1a; 2001b; Bunt, 2000; 2003). However, as Marranci (2008) insisted, the singular use of the term 'Muslim community' has actually inherited an internal paradox of unity and diversity, as both share the same theological and historical roots since the earliest period of Islamic history (see also Tibi, 2001).

In this study, I adopt two analytical perspectives viewing the Ummah as a 'community' and 'collective identity' proposed by Hassan (2006: 314-5) emulating Tönnies' (2001) proposed two models of 'community and (civil) society'. The Ummah is characterized by religious homogeneity, primordial ties and moral or religious cohesion but subsequently transformed and dissolved by increased social differentiation as the Muslim community evolved becoming a worldwide society. The social form of the contemporary Ummah is forged by an associational membership grounded in the capacity of human imagination as members of a communion (cf. Anderson, 1983 on imagined community) amid internal differences and fragmentation. The sense of collectiveness of the Ummah is a product of socialization and identification with fellow co-religionists thus reinforced by a religio-social boundary defining its members and non-members (Hassan, 2006). This collectiveness could be understood as a 'community of feeling', a kind of brotherhood, sisterhood or solidarity amongst Muslims (Marranci, 2008: 112), which can be activated and mobilized as a 'trans-ethnic' and 'transnational' ethos and solidarity for the purposes of diverse sociopolitico events and activities (Marranci, 2009).

Nevertheless, there remains a ques- 
tion on how Muslims actually construe the internal differences within their own religious community. Hirji (2010:9) pointed out that the Muslim construction of the 'other', which in this context not only refers to nonMuslims (e.g. Christians or Jews) but also to 'other Muslims', understood as 'internal others' who is the "most similar or closest to the self ... [having] a distinctive bearing on socio-cultural formulation of the self" (quoted from Smith (2004). In doing so, Muslims reflect their individual religious distinctiveness onto other Muslims and hence become aware of sectarian differences, ethnic and racial divisions and a variety of rituals and ethno-religious traditions that make up the entire Ummah (Eickelman \& Piscatori, 1990). It makes sense to follow Manger's (1999) conclusion that having been living with these internal differences, Muslims are generally aware of the internal diversity, fragmentation and even inconsistencies within their own religious communities. These diversities could either be suppressed to forge a unified Islamic social-political movement or trigger further internal contestation, competition and conflict between different Muslim groups including in diaspora.

\section{Unity, Diversity and Fragmentation}

The Muslim diaspora in the West, if we can use the term, is likely a new phenomenon for Muslims, in which Muslim immigrants coming from diverse religious or non-religious cultural traditions, national backgrounds and having diverse motives for immigration have lived side by side as a minority religious community in non-traditionalist Muslim lands (Esposito, 2002; Dasetto, 2004; Turner, 2010). Yet Moghissi et al (2009: 11) argued cogently that the Muslim diaspora should not be construed as the sole reification of the Ummah that was forged through the shared unity of the Islamic faith and of religious commonalities amongst Muslim immigrants but, importantly, as a reification of their "collective consciousness about group members' marginal location in the larger society in which they reside" (see also Moghissi, 2006; 2010). The prevalence of Islamophobia (Runnymede Trust, 1997; Allen
2005; 2010) and of the securitization of Islam during the global war on terror (Cesari, 2010) have politicized the presence of all immigrants with Muslim heritages. The existence of what Grillo (2004: 865) described as "an imagined coalescence of peoples of different origin and background under the heading Muslim" is correlated with the role and the politicization of religion (Islam) within these immigrant communities.

Nevertheless, the coalescence of Muslims in diaspora is of course not unlimited. As shown by the socio-demographic profile of 2.7 million Muslims in Britain, they are consisted of different ethno-national groups with majority coming from the Indian subcontinent (Indians, Pakistanis and Bangladeshis), the Middle East, Somalia and others (Ansari, 2004; Hussain, 2008; ONS, 2012). They seem to be lack of 'one common origin' and a 'common point of reference' that made them almost impossible to form a 'religious and communitarian organization for the totality of Muslim immigrants' (see inter alia Allievi, 2003: 11). Baumann's (1996) ethnographic study explicates how London Southallian Muslims have retained their ethnic and sectarian primordial affinities irrespective of their religiosity (or lack thereof). In the other words, they are divided by ethnic, racial and sectarian cleavages that occasionally evolve into conflict, contestation, competition and other forms of antagonistic relations between them.

The division of Muslim diaspora can be explained by several aspects. The first one is the existing Islamic religious sectarian divisions in Britain imported from immigrants' home countries, particularly the Middle East (i.e. Hizb ut-Tahrir (the Islamic Liberation Party), Al Muhajiroun (the Emigrants) and the grassroots-oriented Jam'iyat Ihya' Minhaj al-Sunnah (JIMAS) or 'Association to Revive the Way of the Messenger); and South Asia (i.e. Deobandi and Barelwi Maslaqain (sub-schools) and their affiliates such as Tablighi Jamaat and Ahle Sunnah Wal Jamaat) (Gilliat-Ray, 2010; Baskh et al, 2008). Second, the division is triggered by the persisting ethnic-cultural differences and particularly the domination of Indo- 
Pakistani groups. For different reasons, many smaller Muslim groups with different ethno-cultural backgrounds including Somalis (Berns McGown, 1999), Turkish (Kucukcan, 1999); Bosnians (Kelly, 2003) and Arabs (Al-Jahili, 2004) are reluctance to coalesce into the dominated Indo-Pakistani Muslim community. Third, the strong influence of transnational religious ties with their home countries tends to drag certain Muslim groups to disassociate from the dominant one. The influences are linked to the existing transnational Sufi tariqa like Naqshabandi to its parent body in Turkey (Atay, 2012) or Pakistan/India (Geaves, 2000; Werbner, 2003); or the political effort initiated by the home country government like Turkey with its Diyanet to drive and control its overseas community (Schiffauer, 2007).

\section{Indonesian Muslim Immigrants : Ar- rival and their Polarized Religious Trajectories}

The arrival of about 7,000-10,00o Indonesian Muslim immigrants in London ${ }^{1}$ has shown rather different migratory routes and patterns compared to other Muslim immigrants in Britain, who are dominated by labor and economic migrants from the new commonwealth countries, refugees, exiles, asylum-seekers from countries with political connections to the former British Empire, educated professionals and capital investors from oil-rich Arab countries since 1960s1970s (see Ansari 2004; Hussain, 2008). The arrival of Indonesians can be differentiated according to two immigration waves, before and after the 1990s, on the basis of their different motivations and socio-economic backgrounds. In the first wave, a small number of Indonesian immigrants came to London to work either for British companies, branches of Indonesian companies or were appointed as local staff at London's Indonesian embassy. There were also considerable numbers of Indonesian women intermarried with White British men who previously worked in Jakarta. This first wave of Indo-

1 This is a rough estimation based on the 2001 Census reporting the presence about 7,000 Indonesian-born people in Britain (ONS, 2003). nesian immigrants was mostly consisted of educated professionals and/or came from middle-class economic backgrounds.

The next wave of immigration in the 1990 s was motivated by different issues. There were a number of Indonesian students who prolonged their stay along with educated-professional and especially legal and illegal immigrant workers. There was also another group of intermarried Indonesians, not only women with White husbands but also husbands from other minority ethnic groups holding British passports such as Bangladeshis, Pakistanis, Caribbean or Middle Easterners. The legal or illegal semi- and unskilled labor immigrants are mostly females (domestic) workers ${ }^{2}$, who had previously worked in the Middle East. These Indonesian workers are usually mixed with fellow Southeast Asian (e.g. Filipino) co-workers as many of them have received assistance from Kalayaan, a British charity organization assisting migrant domestic workers (see www. kalayaan.org.uk, n.d.).

The two waves of migration have impacted on polarizing the religious trajectories of Indonesian Muslim immigrants in London. I identify three different groups within London's Indonesian Muslim community with regard to their different religious integration trajectories, (i) the traditionalists; (ii) the revivalists; and (iii) the secularists. The term 'traditionalist' refers to Muslim immigrants with orientation of pursuing and reproducing ethno-religious traditions brought in from the home country; and to forming or affiliating to their exclusive ethno-religious-national groups in diaspora (Vertovec, 2009; Ameli, 2002). Most traditionalist Indonesians are part of the 1970s-1980s migration wave as they are largely free from the influence of 1990 Islamic reformism inspired by Middle Eastern transnational Islamic movements among the growing number of urban Muslim middle-

\footnotetext{
2 As reported by the BBC Indonesian Service (7 May 2010), the Home Office issued 1,798 visa permits for Indonesian domestic workers in 2009. This number seemed to fluctuate in 20078 but then remained stable contributing to $12 \%$ of the 16,500 immigrant domestic workers in Britain.
} 
classes in Indonesia (see Hefner, 2000; Eliraz, 2004). The revivalist group, who are part of the post-1990 arrival wave, shows similar orientation to pursue and reproduce their Islamic tradition yet leaning towards the universally standardized (Sunni) religious orthodoxy, influenced by the 1990 s Islamic reformism, and showing readiness to participate into the wider Muslim immigrant associations. In contrast to two groups, the secularists have preferred to adopt the secular culture of British society, as parts of their assimilation path, by individualizing their religiosity, disassociating from any religious association and freeing from any religious authorities (see Cesari, 2004; 2005).

\section{Different forms of Social Relations}

I delineate in this section the ways Indonesian Muslim immigrants in London construe unity and diversity within the Muslim diaspora in regards to their relations with fellow immigrant co-religionists with different ethnic, racial, national and religious sectarian backgrounds. The argument follows Zubaida's (2003) conclusion that the combined factors of diverse ethno-religious trajectories, the impact of western secularization on the individualization of religiosity working together with their multilinear socio-religious integration trajectories, have borne different cultural and religious loyalties and political orientations for different Muslim immigrants. I argue that the idealized concept of Muslim unity and diversity as grounded in the Ummah has been differently construed and experienced by Indonesian immigrants with reference to their polarized religious trajectories, (1) the traditionalists; (2) the revivalists; and (3) the secularists.

\section{The Traditionalists: everyday unity, inevitable diversity}

Framed by their ethno-religious trajectory, the traditionalists Indonesians in London are likely to have fewer interests in joining trans-ethnic Muslim associations or participating in religio-political movements initiated by fellow Indo-Pakistani or Arab co-religionists. Their social interaction with fellow Muslims outside the Indonesian group is limited though the sense of Muslim unity is by no means limited too. Referring to Hassan's (2006) sociological analysis of the Ummah, the traditionalists have construed the idea of Muslim unity in its narrow sense, similar to Tönnies's 'community' as embodied by patterns of religious homogeneity, cultural uniformity and close face-to-face contact. Yet immigration to Britain has opened a new horizon of understanding about the nature of their religious community. Through an encounter with fellow Muslim immigrants from different ethnic, racial and sectarian backgrounds, they have undergone socio-psychological reform in their construal of the 'Muslim other' (cf. Hirji, 2010) and have extended their ethnically and nationally constructed boundaries of the Ummah (cf. Eickelman \& Piscatori, 1990). In other words, the imagined sense of the Muslim community, as socialized and internalized during their upbringing in the home country, has been reified yet transformed socio-culturally by face-to-face social interaction, living side-by-side with fellow immigrant co-religionists and consciously or otherwise sharing a similar status as members of the minority Muslim religious community in London (cf. Moghissi, 2009).

Daily encounters are regarded as the first stage in which traditionalist Indonesians in London meet and make new contacts, experiencing Muslim brotherhood and sisterhood in practice. This is most evident when Muslims acknowledge fellow Muslims and treat them as a brother or sister during everyday life encounters. Acknowledgement of Muslim kinship is a fundamental aspect of unity in the Muslim diaspora. Sudar, a staff of London Indonesian Embassy, told of his personal experience:

To be honest, I haven't made lots of (Muslim) friends outside the Indonesian group. But of course I did hang out and would chat not only with Pakistanis but also Africans like Sudanese or Somalis. It is common that when they realize I am a Muslim from Indonesia, they look very happy about it. It's like they have met an old friend. They appreciate us a lot and call me a brother (Sudar, 5 February 2010) 
For Indonesian women, their public encounter is mediated and marked by the hijab, now perceived as a religiously standardized female dress code (Dwyer, 20oo; Franks, 200o). As many of the traditionalist women do not wear the hijab every day, it is not surprising that their experiences are mixed. Ana, a retired staff of Bruneian Embassy, noticed that the butcher she usually bought poultry from treated her differently depending on whether she was wearing the hijab or not:

I think almost all Muslim sisters are very kind. In my experience, while sitting on the bus or in a restaurant, we greet each other saying 'Assalamu Alaykum' and making small talk. There is a feeling of sisterhood between us. Yet that only happens when I wear this, the Jilbab (or hijab). Moreover, in the supermarket, owned by a Pakistani, I regularly shop there, I always receive special favors. Sometimes he gives me extra poultry or vegetables and helps me to find whatever I need to buy. But every time I shop there without wearing a Jilbab, the special favors are gone. I don't know whether he did that on purpose or just because he doesn't recognize me when I dress in my Jilbab (Ana, 23 March 2010).

Similarly, Beti stated that fellow IndoPakistani Muslims only greet her when she wears a hijab on her way to the office. For men, the process of recognising fellow Muslims takes a bit longer. They have to get to know each other by having a conversation or meeting in a supposed Islamic religious place like a mosque. For traditionalist Indonesians in London, the everyday acknowledgement of kinship with fellow Muslims regardless of their ethnic or racial background, as Otto said, 'has proved the universality of Islam' (Otto, 17 May 2010).

As an imagined form of Muslim kinship, the acknowledgement of kinship has embodied both the symbolic connotation and the real meaning. Symbolically, acknowledgement denotes an intimate relationship, friendliness and a warm welcome shown to and by fellow Muslims. This can be seen in Marranci's (2008) explanation that Ummah means a 'community of feeling', in which Muslims share a sense of belonging and experience kinship bonds in their daily encounters. This symbolic reification, however, can be transformed into a genuine kinship alliance especially in the diasporic circumstances of Muslim immigrants as they share both marginalisation and exclusion and being targeted by anti-Muslim hate sentiments and public securitisation (see Moghissi, 2009).

The idea of Muslim unity has further reified by a readiness to share a will and preparedness to give help, assistance and protection to fellow Muslim immigrants. As storied by Rodiah, a domestic worker, she received lots of assistance in finding shelter and work from members of the women's group at the East London Mosque after voluntarily choosing to stay in London while her employers went home to Oman. Similarly, in the heyday of Islamophobia after the London bombing in 2005, Ana aroused suspicion because of wearing a hijab on her way home and was offered protection from the suspicious eyes of people surrounding her, by a Pakistani man wearing a shalwarkameez ${ }^{3}$.

Another experiential event - involvement in mosque congregations and socioreligious organizations to perform rituals and prayers, religious sanctioned practices or other socio-religious activities - has two different meanings, (i) as a further platform to exercise a sense of Muslim unity and (ii) as a testing ground for the construction of internal Muslim diversity both in terms of different ethno-religious traditions and sectarian fragmentation. Joint congregations in the mosque (e.g. the Friday Prayer) or the joint celebration of Islamic feasts (e.g. the Eid ul-Fitr) is an opportunity for Muslim immigrants to share their feelings as part of the (diasporic) Muslim community while at the same time to form an awareness of internal Muslim diversity and fragmentation (cf.

3 Shalwar-Khameez is a traditional dress originally coming from South and Central Asia that worn by people of India, Pakistan, Afghanistan and Bangladesh. 
Eickelman \& Picastori, 1990).

For this traditionalist group, nevertheless, the opportunity to join a congregation in a local mosque or get involved in associations and cultural religious activities initiated by fellow Indo-Pakistani Muslims is unfortunately very limited. There exist both external and internal obstacles that hinder them from doing so. An external obstacle is that mosques across London are run by ethnic-based organizations; the majority of congregations and activities are designed to serve a particular ethnic group with the medium of a vernacular language (e.g. Urdu in Pakistani-affiliated mosques and Bengali or Bangla in Bangladeshi ones) (Lewis, 1994; Ansari 2004; Gilliat-Ray, 2010 and many others). This tendency ultimately limits the participation of Muslim immigrants from other ethnic backgrounds including Indonesians. For women, opportunities are even more limited as most of these mosques do not provided any space for female congregants.

An internal obstacle comes, at first, from the fact that most traditionalists, particularly males are busy with work; they have fairly limited time allocated to socioreligious activities except the primary ones. Second, due to the lack of English fluency, their modest educational attainment and economic background have meant that they lack sufficient confidence to participate in wider diasporic Muslim associations. Third, the reluctance to join a mosque congregation or a Muslim association also has something to do the preference to stay close to fellow ethno-nationals and pursue their ethno-religious Indonesian tradition. As a result, the experience of Muslim unity within the traditionalist Indonesian Muslim group in London is by no means superficial, trivial and/or accidental as illustrated by the acknowledgement of kinship and the readiness to offer everyday help to fellow Muslims. Many preferred to have limited contact and/or to live rather separately from fellow Indo-Pakistani Muslims in order to avoid misunderstandings or conflicts while at the same time acknowledge the shared Islamic faith. Ana presented such an argument to me:

Though we are all Muslims, our Islamic traditions are so different to Pakistanis or Arabs. It is better for both of us not to disturb each other by limiting our encounters. Moreover, we also speak different languages. So, let Indonesians group with other Indonesians and Pakistanis with Pakistanis. We might join in the Malaysian group as we share lots of cultural commonalities. But with Indians or Pakistanis, it would be difficult to get close enough because we have so many cultural differences (Ana, 23 March 2010).

Given the fact that traditionalist Indonesian Muslims have formed their own exclusive religious groups, namely pengajian, they seek there a refuge from their alienation from British secularized society rather than incorporate into the Indo-Pakistani, Bangladeshi or Somali religious associations. The propensity to have a separated socio-religious life is considered similar to the pattern of social interaction between different ethnic groups in Britain characterized by limited contact yet living in the same neighborhood, popularly called the 'parallel life' (cf. Cantle, 2004; Philips, 2006).

For other traditionalist Indonesian Muslims, who do not participate in pengajian due to some reasons and have no other choice but to join fellow Pakistani or Bangladeshi groups in order to fulfil their main religious needs, they tend to ignore the cultural or sectarian differences and take more interest in core religious commonalities shared by both sides. Rodiah has an interesting view:

I thought there were more commonalities rather than differences in our religiocultural practices. I know that Pakistani women do not go to the mosque. Their religious activities are mostly held at home. Sometimes, I am invited to join their Qur'anic recitation groups. I also like to join the Somali groups. As they are native Arabic speakers, their Qur'anic recitations are definitely better than ours. So, I expect they criticise my pronunciation. They also comment on my short hijab, which accor- 
Jurnal Komunitas 6 (2) (2014): 197-211 205

ding to them is not religiously proper for Muslim women. But I tell them, "I am not comfortable with their Abaya ${ }^{4}$, my hijab is more than enough". They did not bring it up again. So far, I am OK with them (Rodiah, 5 May 2010).

Similarly, Hamim, who is known as an Imam of the Indonesian Muslim community in London, insisted that internal Muslim differences and fragmentation should be treated as a blessing from God. He referred to a hadith to justify this view ${ }^{5}$. As a religiously knowledgeable person, Hamim gave me a detailed lecture on various differences between the prayers (e.g. the Friday sermon, run in mosques surrounding his home in Tower Hamlets affiliated to Bangladeshi or Pakistani groups). He further argued that in order to imagine the idea of Muslim unity, we must respect any internal Muslim ethnic and sectarian differences.

To sum up, internal community diversity and fragmentation, as far as they are concerned, is taken for granted in the Muslim community and is not something they concern themselves with. This perception thus significantly affects how they interact with fellow non-Indonesian Muslim immigrants.

\section{The Revivalists: unity realized, diversity suppressed}

Compared to fellow traditionalists, the revivalist Indonesian Muslims in London have faced similar external obstacles to initiating social contacts and actively participating in mosque congregations and larger British Muslim associations. For revivalist Indonesians, the existing language gaps and the st-

4 Abaya is a simple, loose over garment or a robe-like dress worn by female Muslims as part of their religious lifestyle, which is very popular in Muslim countries like Saudi Arabia and North Africa but not in other countries like Pakistan and Indonesia. The cloth is designed to cover the whole body except the face, feet and hands.

5 The hadith stated that the Prophet Muhammad once said, "Ikhtilafu ummati rahma" (literally meaning "the diversity within the Ummah is a sign of God's blessing"). However, the authenticity of the hadith has been widely questioned by Muslim scholars (see Masud, 2009). rong ethnic affinities in the mosque organizations or wider Muslim social associations have ultimately left them as no more than ordinary participants. The incorporation of both traditionalist and revivalist Indonesians Muslims into the wider minority British Muslim community has been fairly limited. However, their religious trajectory of leaning toward the universally standardized (Sunni) Islam has constructed a deeper internalization of the theologically normative concept of Muslim unity amid the internal diversity and fragmentation of the Muslim community which have both been transplanted in the diaspora. As I will discuss later, these revivalist Indonesians in London have shown more eagerness to coalesce with fellow Muslim immigrants surpassing their ethnic, racial and sectarian lines (cf. Zubaida, 2003). This socio-religious propensity is more or less correlated with, on the one hand, their higher level of educational attainment, better economic backgrounds and, on the other, the internalised spirit of worldwide politico-religious revivalism since the 1979 Islamic revolution in Iran. The former has given them a greater sense of confidence to encounter and participate in the wider Muslim community. The latter has built a sense of awareness regarding the need for Muslim immigrants to unite in order to circumvent the marginalization, discrimination, negative stereotypes and anti- Muslim hate attacks from the wider society of London (cf. Moghissi, 2008; 2009).

The cultural open mindedness to 'Muslim others' is illustrated by the way they make sense of the imagination of Muslim kinship in the Muslim diaspora in London. As religiously devout practicing Muslims, they have more opportunities to encounter fellow co-religionists due to their more active involvement in various religious events (e.g. Friday sermons and other prayers in mosques) and other socio-economic activities that only devout Muslims take part in (e.g. buying halal meat in local butcher shops). The revivalists have developed more intimate friendships with fellow Indo-Pakistani, Arab or African Muslims. Wahyu, a journalist, explored his experiences below. 
I've felt lucky, honestly, as I've found out my next door neighbors are Muslims, one from Egypt, one from Nigeria. We first met in a nearby mosque. It was just a spontaneous reply to one another, "oh, you're a Muslim?” As we shared many (religio-cultural) commonalities, it was easy to carry on the conversation and talk about lots of things related to our religion, we became close friends. During Ramadan, we went to the mosque and had an Iftar (evening meal) together with our families. I would say that we really connected because of Islam. So, there is no hesitation or awkwardness that prevents us asking for help, visiting each other's homes or exchanging ethnic food (Wahyu, 9 May 2010).

A similar experience was also had by Ning, who showed an eagerness to get to know her fellow Muslim neighbors since the first time she and her husband moved to a Bangladeshi dominated neighborhood in Tower Hamlets.

I thought it was a pity not to get to know our Muslim neighbors. So, I knocked on their door, greeted them 'Assalamu 'Alaykum', and asked whether they were Muslims. They welcomed us warmly. We later found out that they came originally from Bangladesh. Our friendship has become close, as they treat me like a member of their family. There were two sons and one daughter. They now treat me as an elder daughter. When their sons and daughter were going to marry, their father said that they must ask for my approval. So, he insisted that I attend the engagement ceremonies and give my opinion on the brides and bridegroom. Unfortunately, they moved to Barking a couple of years ago, but of course we have kept in touch (Ning, 1 February, 2010).

As a housewife, Ning has much more free time during the weekdays, which has allowed her to participate in various local socio-religious activities. As someone with a degree on Islamic education from an Indonesian university, she also has sufficient confidence to provide private courses on Qur'anic and Islamic teachings for British Bangladeshi children in her neighborhood. For her, it is easy to interact with fellow Mus- lims and build close friendships.

Many revivalist Indonesians have joined the mosque congregation nearby their home or participated in wider transethnic Muslim associations or organizations motivated by their intentions to learn Islam a more serious way. As exemplified by Sri, having admitted to being less knowledgeable on Islamic religious teachings given that her husband is a white Muslim convert, she came to feel responsible for maintaining the family religiosity living in the secularized British social environment. As a successful businesswoman with Indonesian-Arab heritage, Sri has the confidence and certainty to join the congregation in a local mosque.

I have been a member of the Al-Muntada Al-Islami mosque congregation for years. It started with my concerns about religious education for my children. As there was a Sunday Arabic and Qur'anic class for kids in the mosque, I sent them there. The class was not so good but there was no other choice. I often had quarrels with the principal. Because of that, he invited me to be part of the education committee of the Al-Muntada Al-Islami mosque ... Later, I also attended some short courses on Arabic and Islamic teachings run by the mosque (Sri, 17 January, 2010).

The eagerness to participate in a local mosque congregation or other Muslim associations is also expressed by Usman, a journalist, and Dicky, an IT consultant. Usman had actively involved in the 'City Circle $^{6}$, though later declined because of busy with works and organizing socio-religious activities within the Indonesian community. Nowadays, his socio-religious activities outside the Indonesian communal group revolve around occasional attendance at Islamic religious talks in a nearby Bangladeshidominated mosque, if delivered in English instead of Bangla, and in the London Central Mosque at Regent's Park. For Dicky, his eagerness is apparent in his becoming an

6 The City Circle is an voluntary Muslim organization based in the central of London run by young professional Muslims across ethnic and sectarian groups in London. For detail, see http://www.thecitycircle.com, n.d. 
active member of the South Asian Islamic missionary group, Tablighi Jamaat. In this conservative Islamic group, Dicky has found a refuge from the alienation of secularized British society after migrating to this country.

These revivalist Indonesians in London have also shown eagerness and readiness to participate in politico-religious British Muslim movements (e.g. mass protests or rallies) to articulate political demands related to local and international Islamic affairs. Compared to their traditionalist Indonesian counterparts, they have shown a stronger sense of Muslim kinship and solidarity and have felt compelled to express this by taking action. During my fieldwork, I observed many revivalist Indonesians taking part in the mass protest on $31^{\text {st }}$ May 2010 organized by the Stop the War Coalition along with various Muslim organizations; the protest was about the shooting by Israeli commandos of nine Turkish humanitarian activists on board the Mavi Marmara, the flotilla aid ships bound for Gaza. The protesters marched from Downing Street to the Israeli Embassy at Kensington. Based on the information I gathered during and after the protest, it was not the first time those revivalist Indonesians like Wahyu, Usman or Ning took part in protest to articulate their views on local and international Islamic affairs. They first took part in the public march against the Iraq war in mid February 2003. As Usman said:

I started joining the mass rallies organized by Stop the War Coalition with other Muslims in 2003. We were informed that the US and Britain were determined to invade Iraq. We knew that the previous invasion to Afghanistan had caused lots of civilian casualties including women and children. We did not want the same tragedy to happen in Iraq. Literally, I was encouraged to join the action to show my solidarity with our brothers and sisters in Iraq (Usman, 29 January 2010).

The fervent participation of the revivalist Indonesians in those protests is a robust example of how Muslim immigrants can be mobilized to take a stand against un- fair treatment faced by fellow co-religionists as a reification of the Muslim kinship, solidarity and collective identity in diaspora (cf. Moghisi, 2009). Wahyu gave an interesting remark below:

[In London,] the ukhuwah ul-Islamiyah (Muslim kinship) might not be structurally defined, not yet, but I've really felt it. Let me give an example, when Gaza was attacked, I found Muslims from any ethnic, racial and national background took a stand together shoulder-to-shoulder to protest in public. It is clear to me that all of us are bonded, united by brotherhood, (sisterhood) and solidarity in the name of Islam (Wahyu, 9 May 2010).

As Marranci (2009) added, Muslims, under the banner of Ummah unity, have been obliged by religion to stand together, forgetting their internal differences, to give help and protection to their fellow suffering Muslims. In the diasporic condition, the understanding of Muslim unity has evolved from a narrowly ethnic and territorial-based homogenous community to a trans-ethnic and de-territorialized pluralistic society (Hassan, 2006). The collective identity of Muslim immigrants has been forged and nurtured by their shared feeling of being threatened or targeted for unjustified actions, not by the uniformity of religio-cultural traditions (Mandaville, 2001).

\section{The Secularists: implausible unity, ir- reconcilable diversity}

Owing to their socially secularized trajectory, the secularist group has almost no interest in incorporating into the ethno-religious community of Indonesians in London and/ or the larger minority British Muslim community or in showing their sympathy and support for the politico-religious initiatives of British Muslim movements. As Zubaida (2003) noted, their secularized religious trajectory has diminished their sense of belonging, solidarity and co-responsibility with fellow immigrant co-religionists though facing similar forms of marginalization and exclusion from wider society. The idealized concept of Muslim unity grounded in the 
Ummah is implausible for them. The persisting internal ethnic and sectarian differences and fragmentation have convinced them of the impotency of the theological normative idea to boost the coalescence of all Muslim immigrants in London as a unified minority religious community.

The indifferent attitude toward the idea of Muslim unity can be seen in their very limited interaction with fellow IndoPakistani, Somali or Bangladeshi Muslim immigrants. However, there exist various different reasons for this in addition to their indifferent attitudes to their fellow immigrant co-religionists. For some who intermarried with White Britons, it is because they have been dwelling in white dominated neighborhoods with only a few Muslim immigrants residing there. This is illustrated by Ratna, having been residing in Beckenham, South East London for about thirty years; she admitted to not having any IndoPakistani or Black friends or acquaintances except the husband of one of her cousins;

I really do not have any close Pakistani or Black friends. It does not mean I am racist. But you know, there are barely any Blacks, Indians or Chinese people living in this area (Beckenham). My husband once asked me, are you a racist? I'm definitely not! I have made friends with many people here as I work at the Care House. But it is true, I've just realized, no Indians, Blacks or Pakistanis have ever entered this home except my cousin's husband, Suhal, a Pakistani. I think it is just because I do not want to cause problems for myself. I mean because I have a different religious orientation, being a non-practicing Muslim, I do not want to quarrel with them (Ratna, 10 May 2010).

For others who reside in multi-ethnic and multi-faith neighborhoods, their very limited contact with fellow Indo-Pakistani or Somali Muslims is more or less due to the existing ethno-cultural gap between Muslim immigrants. The ethno-cultural barrier is also experienced by other Indonesian groups, particularly the traditionalist one. Being required neither to observe Islamic rituals or other sanctioned religious practices (e.g. attending Friday sermon or joining Islamic classes), nor to have a strong religiocultural or political bond with other Muslim immigrants, there are barely any events or activities that bring secularist Indonesians together with fellow Indo-Pakistani or Somali Muslims. In a comment typifying the views of this group, Ridwan said that his friendship with Bangladeshi neighbors at Tower Hamlets has not improved much since he first moved there around the early 1980 s. Besides admitting to having very little intention to get to know them, he noticed that they were also busy with their own ethnocommunal activities with no apparent intention to get to know him either. The pattern of social interaction between secularist Indonesians and fellow Muslim immigrants is fairly similar to their traditionalist Indonesian counterparts, adopting the 'parallel life' model by sharing the same neighbourhood but living in a separated ethno-religious social space (see Cantle, 2004; Philips, 2006).

In addition to the ethno-cultural gap, secularist Indonesians have generally held a negative impression of any ethnoreligious communities and activities, which are perceived to be irrelevant to pursue in the immigrant lands, being incompatible with Western secular culture, and regarded as the embryo of radical Islamist movements. This indifference has been influenced by the general stigmatization of Islam and Muslims in Western mainstream media. Referring to Eickelman and Piscatori (1990) and Hirji (2010), the secularist Indonesian Muslim group has also faced the problem of defining 'Muslim others' encountered in the diaspora. While revivalist Indonesians tend to extend their perception of Islam beyond their ethno-national lines, these secularist Indonesians are reluctant to do so.

The lack of conviction of the secularists regarding the articulation of the idea of Muslim unity in the diaspora is grounded in a common understanding of the irreconcilable internal diversity and fragmentation within Islam. For them, combined with the various unresolved international problems related to Muslims (e.g. the Israeli-Palesti- 
nian conflict or the rampant poverty in Muslim countries in Africa), the efficacy of the theologically normative idea of Ummah unity espousing kinship solidarity within the (worldwide) Muslim community has lost its meaning. This opinion is clearly expressed by Ridwan below:

\begin{abstract}
I believe there is no unity among Muslims. They might band together in doing prayers at the mosque or to fight handin-hand against the common enemy. But unity only emerges in particular situations. For example, when Palestine was attacked, Muslims would gather for a mass rally, a public protest and to give support like donations etc., as many Indonesians here do also. But in a broad sense, it changed nothing. To see Muslims work together, stand shoulder-to-shoulder neglecting their ethnic or national group, it will never happen. To find Muslims across the world working together eradicating poverty in Africa, you know many of them are Muslims, I don't think it will ever happen (Ridwan, 11 February 2010).
\end{abstract}

Their skepticism regarding the unity of the Muslim diaspora is not surprising. Since they prefer to see religion as a private matter detached from the public sphere, there is no need for them to band together with fellow immigrant co-religionists or to display to the public a united minority religious community in order to gain wider recognition.

However, it must be noted that their Muslim heritage has created a shared psychological sense of Muslim solidarity (see Moghissi, 2009). For the secularist Indonesians, the intention to abandon their ethno-religious identity and assimilate into the secularized culture of British society has not necessarily rescued them from awareness of their Muslim heritage. There exists a shared feeling of being victimized by the current internationalization of Islamic affairs and the ongoing negative stigmatization and securitization of Islam in diaspora (Moghisi, 2009). Ridwan explained his thoughts below:

Regardless of my Muslim heritage, I am
Jurnal Komunitas 6 (2) (2014): 197-211 209

very critical of how the West (the British and US government) treat Muslims unfairly. For example, on the Israeli-Palestinian conflict, it is very obvious how they (the West) have a different agenda, which will never to solve the problem. As long as the West treats them unfairly, particularly the Palestinians, the conflict will continue. (Immigrant) Muslims in Britain, as I know well, have lived peacefully for years without any major problems with the locals. Just a couple of years ago, we saw a Jihadi terrorist attack here (i.e. the London bombing in 2005). This only happened after the British army got involved in the unjustified military invasion of Afghanistan and Iraq. Before, they (Muslims) were not a threat (to homeland security) but the Irish were, you knew that, didn't you? In this situation, I definitely take sides with the Muslims. I admit that I am not a practicing Muslim and pay no attention to any Muslim communities (or politics) here. But if somebody attacks Islam unjustifiably, I feel a bit offended, I feel uncomfortable with it. I don't know why? Am I not able to escape from my Muslim heritage? (Ridwan, 11 February 2010)

Needless to say, though admitting being secularized with no intention to conform to ethno-religious rules and to disassociate instead from the immigrant minority religious community, some of the secularist Indonesians in London have retained a shared socio-religious solidarity to fellow Muslims elsewhere. Referring to Marranci (2009) again, this fact illustrates that the normative unity of the Muslim community as a 'community of feeling' in which every Muslim with different ethno-religious or non-religious backgrounds and propensities might keep it without necessarily expressing it in any form.

\section{CONCLUSION}

In the article, I argue that the relationship and coalescence between Indonesians and fellow Muslim immigrants in London have been differently constructed and experienced on the basis of their polarized religious trajectories, (1) the traditionalists; (2) the revivalists; and (3) the secularists. The issue 
has particularly examined the applicability of the normative yet paradoxical concept of unity and diversity within the Ummah in the context of the Muslim diaspora. For the traditionalists, the unity of the Ummah has been construed as a trivial matter surpassed by factual ethno-cultural and sectarian differences of the Muslim diaspora, which shapes their limited social relationship with fellow Muslim immigrants. For the revivalists, they have construed the unity of the Ummah as an idealized concept in order to overcome the ethnic and sectarian diversity and fragmentation of the Muslim diaspora. This understanding has driven them to build rather more close social relations with fellow Muslim immigrants and to participate in the wider minority Muslim associations. In contrast to the other two groups, the secularists have become disillusioned with the unity of the Ummah in the diaspora, which has led them to have fewer interests in building close social relationships with fellow Muslim immigrants and associating with any minority Muslim social or political associations.

\section{REFERENCES}

Al-Jahili, I. 2004. Arab population in the UK: An ethnic profile. Retrieved 24 June, 2010, from http:// www.naba.org.uk/content/theassociation/Reports/arabpopuk_04

Allen, C. 2005. From race to religion: The new face of discrimination. In Tahir Abbas (Ed.), Muslim Britain: Community under pressure (pp. 4965). London: Zed Books.

Allen, C. 2010. Islamophobia. Surrey, Burlington: Ashgate.

Allievi, S. 2003. Islam in the public space: Social networks, media and neo-communities. In Stafano Allievi \& Jorgen Nielsen (Eds.), Muslim networks and transnational communities in and across Europe (pp. 1-27). Leiden: Bril.

Ameli, S.R. 2002. Globalization, Americanization and British Muslim Identity. London: ICAS.

Ansari, H. 2004. 'The infidel within: Muslim in Britain since 180o. London: Hurst and Company.

Atay, T. 2012. A Muslim Mystic Community in Britain: Meaning in the West and for the West. Bremen: EHG.

Baksh, N., Cantle, Ted, Lempriere, J., \& Kaur, D. 2008. Understanding and appreciating Muslim diversity: Toward better engagement and participation. Coventry: Institute of Community Cohesion.

Baumann, G. 1996. Contesting culture: Discourse of identity in multi-ethnic London. Cambridge: Cambridge University Press.

Berns-mcgown, R. 1999. Muslims in the diaspora: The Somali communities of London and Toronto. Toronto: University of Toronto Press.

Bunt, G.R. 200o. Virtually Islamic: Computer-mediated communication and cyber Islamic environments. Cardiff: University of Wales Press.

Bunt, G.R. 2003. Islam in the digital age: E-jihad, online fatwas and cyber Islamic environments. London: Pluto Press.

Cantle, T. 2001. Community Cohesion: A Report of the Independent Review Team. London: HMSO.

Cesari, J. 2004. When islam and democracy meet: Muslims in europe and in the united states. New York: Plagrave Macmillan.

Dasetto, F. 2004. Muslims in Western Europe: Sociohistorical developments and trends. In Sato Tsugitaka (Ed.), Muslim societies: Historical and comparative aspects (pp. 137-155). London: routledgecurzon.

Dwyer, C. 200o. Negotiating diasporic identities: Young British South Asian Muslim women. Women's Studies International Forum, 23(4), 475-486.

Eickelman, D.F. \& James, P. 1990. Social theory in the study of Muslim societies. In Dale F Eickelman \& James Piscatori (Eds.), Muslim travellers: Pilgrimage, migration and religious imagination (pp. 3-28). California: Routledge.

Eliraz, G. 2004. Islam in indonesia: Modernism, radicalism and the Middle East dimension. Brighton: Sussex Academic Book.

Esposito, J.L. 2002. The Muslim Diaspora and the Islamic world. In Shireen T. Hunter (Ed.), Islam Europe's second religion: The new social, cultural and political landscape. London: Praeger.

Franks, M. 200o. Crossing the borders of whiteness? White Muslim women who wear the hijab in Britain today. Ethnic and Racial Studies, 23(5), 917-929.

Geaves, R. 200o. The Sufis of Britain: An exploration of Muslim identity. Cardiff: Cardiff Academic Press.

Gilliat-Ray, S. 2010. Muslims in Britain: An introduction. Cambridge: Cambridge University Press.

Grillo, R. 2004. Islam and Transnationalisn. Journal of Ethnic and Migration Studies, 30(5), 861-879.

Hassan, R. 2006. Globalisation's challenge to the Islamic Ummah. Asian Journal of Social Science, 34(2), 311-323.

Hefner, R.W. 200o. Civil islam: Muslims and Democratisation in Indonesia. New jerset: princeton university press.

Hirji, Z. 2010. Debating Islam from within: Muslim constructions of the internal other. In Zulfikal Hirji (Ed.), Diversity and pluralism in Islam: Historical and contemporary discourses amongst Muslims (pp. 1-30). London: I.B. Tauris.

Hussain, S. 2008. Muslims on the map: A national survey of social trends in Britain. London: Tauris 
Academic Studies.

Iosifides, T. 2011. Qualitative Methods in Migration Studies: A Critical Realist Perspective, Farham, Ashgate.

Kelly, L. 2003. Bosnian refugee in Britain: Questioning community. Sociology, 37(1), 35-49.

Kücükcan, T. 1999. Politics of ethnicity, identity and religion: Turkish Muslims in britain. Aldershot: Ashgate.

Lewis, P. 1994. Islamic Britain: Religion, politics and identity among British Muslim: Bradford in the 1990s. London: I.B. Taurus.

Mandaville, P. 20o1a. Transnational Muslim politics: Imagining the Umma. Oxon: Routldge.

Mandaville, P. 20o1b. Reimagining Islam in diaspora: The politics of mediated community. Gazette, 63(2-3), 169-186.

Manger, L. 1999. Muslim diversity: Local Islam in global contexts. In Leif Manger (Ed.), Muslim diversity: Local Islam in global contexts (pp. 1-36). Oxon: NIAS and routledgecurzon.

Marcus, G. E. 1995. Ethnography in/of the World System: the Emergence of Multi-sited Ethnography. Annual Review of Anthropology 24, 95-117.

Marranci, G. 2008. The Anthropology of Islam. New York, US: Berg.

Marranci, G. 2009. Understanding Muslim identity: Rethinking fundamentalism. London: Palgrave Macmillan.

Moghissi, H. 2010. Introduction. In Haideh Moghissi (Ed.), Muslim diaspora in the west: Negotiating gender, home and belonging (pp. 1-10). Farnham: Ashgate.

Moghissi, H (Ed.). 2006. Muslim diaspora: Gender, culture and identity. Oxon: Routledge.

Moghissi, H., Rahnema, Saeed, \& Goodman, Mark J.
Jurnal Komunitas 6 (2) (2014): 197-211

2009. Diaspora by design: Muslim immigrants in canada and beyond. Torronto, Buffalo, London: The University of Torronto Press.

Nadai, E. \& Maeder, C. 2005. Fuzzy Fields: Multi-Sited Ethnography in Sociological Research. Forum Qualitative Social Research, 6.

ONS. 2012. Religion in england and wales 2012. Retrieved from http://www.ons.gov.uk/ons/rel/ census/2011-census/key-statistics-for-localauthorities-in-england-and-wales/rpt-religion.html

Philips, D. 2006. Parallel lives? Challenging discourses of British Muslim self-segregation. Environment and Planning Deevelopment, 24, 25-40.

Runnymede-Trust. 1997. Islamophobia: A challenge fo us all. London: Runnymede Trust.

Schiffauer, W. 2007. From exile to diaspora: The development of transnational Islam in Europe. In Aziz AL-Azmeh \& Effie Fokas (Eds.), Islam in europe: Diversity, identity and influence (pp. 68-95). Cambridge: Cambridge University Press.

Tibi, B. 2001. Islam between culture and politics. New York: Palgrave.

Tonnies, F. 2001. Community and civil society. Cambridge: Cambridge University Press.

Turner, B.S. 2010. Islam, diaspora and multiculturalism. In Akbar S Ahmed \& Tamarra Sonn (Eds.), The Sage handbook of Islamic studies (pp. 1733). London: Sage.

Vertovec, S. 2009. Transnationalism. Oxon: Routledge.

Werbner, P. 2003. Pilgrims of love: The Anthropology of a global Sufi cult. London: C. Hurst and Co.

Zubaida, S. 2003. Islam in Europe. Critical Quaterly, 45(1-2), 88-89. 